\title{
Penyebab Miskonsepsi Siswa Kelas 9 pada Materi Pecahan Bentuk Aljabar Berdasarkan Teori Konstruktivisme
}

\author{
Djadir $^{1, a)}$, Nurdin Arsyad ${ }^{1, b)}$, dan Melda Datu Kalu ${ }^{1, c)}$ \\ ${ }^{1}$ Jurusan Matematika FMIPA Universitas Negeri Makassar \\ a)djadir@unm.ac.id \\ b)nurdin.arsyad @unm.ac.id \\ c)meldadk1198@gmail.com
}

\begin{abstract}
Abstrak. Penelitian ini bertujuan untuk mengetahui faktor penyebab terjadinya miskonsepsi siswa pada materi pecahan bentuk aljabar kelas 9 ditinjau dari prinsip-prinsip teori belajar konstruktivisme. Jenis penelitian ini adalah penelitian kualitatif dengan menggunakan pendekatan deskriptif. Subjek dalam penelitian ini adalah 5 siswa kelas 9 yang mengalami miskonsepsi terbanyak dengan nilai terendah. Instrumen yang digunakan dalam penelitian ini adalah tes diagnostik miskonsepsi siswa yang terdiri dari beberapa butir soal uraian disertai dengan skor tingkat kepercayaan (CRI) dan pedoman wawancara. Prinsip-prinsip teori belajar konstruktivisme yang dimaksud dalam penelitian ini adalah lingkungan belajar, pengetahuan awal siswa, kemampuan siswa, keaktifan siswa dalam pembelajaran dan pengalaman belajar siswa. Hasil penelitian menunjukkan bahwa terjadinya miskonsepsi disebabkan oleh beberapa faktor baik dari segi internal maupun eksternal ditinjau dari prinsip-prinsip teori konstruktivisme.
\end{abstract}

Kata Kunci: Miskonsepsi, Konstruktivisme, CRI, Pecahan, Aljabar

\begin{abstract}
This study aims to determine the factors that cause student misconceptions form 9th grade on algebraic form fraction in terms of the principles of constructivism learning theory. This type of research is qualitative research using a descriptive approach. The subjects in this study were 5 grade 9 students who experienced the most misconceptions with the lowest scores. The instrument used in this study was a student misconception diagnostic test consisting of several descriptive items accompanied by Certainty of Response Index (CRI) and an interview guide. The principles of constructivism learning theory referred to in this study are the learning environment, students' initial knowledge, student abilities, student activeness in learning and student learning experiences. The results showed that the misconception was caused by several factors, both internal and external, in terms of the principles of constructivism theory.

Keywords: Misconception, Constructivism, CRI, Algebraic, Fractions
\end{abstract}

\section{PENDAHULUAN}

Miskonsepsi atau salah konsep menunjuk pada salah satu konsep yang tidak sesuai dengan pengertian ilmiah yang diterima pakar di bidang itu (Suparno, 2013;Ningrum \& Budiarto, 2016). Miskonsepsi terjadi akibat kesalahan dalam menafsirkan makna sebuah konsep yang berbeda dengan konsep ilmiah dan tidak ada tindakan untuk memperbaikinya. Siswa yang sering mengalami miskonsepsi, akan kesulitan dalam menghubungkan konsep yang satu dengan konsep lainnya. Hal ini bisa menghambat pengembangan pemahaman konsep pada siswa serta menghambat proses pembelajaran yang berlangsung (Artiawati, Muliyani \& Kurniawan, 2016).

Salah satu materi matematika yang membuat siswa mengalami miskonsepsi adalah pecahan. Materi pecahan telah diberikan dan dipelajari oleh siswa ketika mereka duduk di bangku 
Sekolah Dasar (SD). Pada saat kelas 7, siswa telah diberikan dan mempelajari materi pecahan dalam bentuk aljabar. Pemahaman awal siswa pada materi pecahan bentuk aljabar yang pernah diterima dan dipelajarinya, kadang akan berbeda dengan konsep ilmiah yang diterima kemudian. Berdasarkan hasil observasi awal yang dilakukan, ditemukan beberapa siswa melakukan kesalahan dalam menyelesaikan soal-soal yang diberikan terkait pecahan bentuk aljabar.

Penelitian tentang miskonsepsi pecahan bentuk aljabar telah banyak dilakukan. Munawaroh (2017) menganalisis miskonsepsi siswa kelas 8 berdasarkan minat belajar. Sedangkan, Savitri (2014) menganalisis miskonsepsi siswa kelas 8 berdasarkan gaya belajar. Hasil penelitiannya menunjukkan bahwa miskonsepsi siswa disebabkan oleh penalaran yang tidak lengkap, kurangnya kemampuan dalam memahami serta mengingat materi yang telah dipelajari. Selain itu, Jannah (2018) menyebutkan bahwa faktor penyebab miskonsepsi siswa yaitu kurang mahir dan kurang teliti dalam melakukan operasi hitung, kurangnya pemahaman akan prinsip dan konsep pada materi pecahan aljabar.

Artikel ini membahas tentang faktor penyebab miskonsepsi siswa pada materi pecahan bentuk aljabar kelas 9. Siswa yang dipilih sebagai subjek adalah yang mengalami miskonsepsi terbanyak dan akan diwawancarai untuk mengetahui faktor penyebab miskonsepsi berdasarkan teori konstruktivisme.

Konstruktivisme adalah suatu pendekatan yang berkeyakinan bahwa orang secara aktif membangun atau membuat pengetahuannya sendiri dan ditentukan berdasarkan pengalamannya (Paradesa, 2015). Secara filosofis terjadinya miskonsepsi dapat dijelaskan dengan filsafat konstruktivisme, bahwa pengetahuan dikonstruksi oleh siswa sendiri dalam kontak dengan lingkungan, tantangan, dan bahan pelajaran yang dipelajari (Salamah, 2015). Konstruktivisme digunakan sebagai acuan untuk membangun kelas yang memaksimalkan siswa belajar.

\section{KAJIAN PUSTAKA}

\section{Miskonsepsi}

Miskonsepsi dapat diartikan sebagai kesalahan yang dilakukan oleh siswa yang diakibatkan karena pemahaman yang kurang tepat (Rahmah, Dassa \& Ramdani, 2019). Miskonsepsi terjadi karena terdapat pemahaman yang salah dalam pengetahuan siswa (Leinhardt, Zaslavsky \& Stein, 1990). Lebih mendetail, miskonsepsi adalah pemahaman yang tidak akurat akan konsep, ketidakmampuan dalam menghubungkan konsep awal dengan konsep selanjutnya secara benar dan bersifat resisten/sulit diubah (Malikha \& Amir, 2018).

Sebuah miskonsepsi terjadi ketika seseorang meyakini sebuah konsep benar yang secara obyektif salah (Muzangwa \& Chifamba, 2012). Sehubungan dengan sifat subyektifitas yang dimiliki manusia, dapat diasumsikan bahwa setiap orang selalu memiliki sebuah miskonsepsi. Jika sebuah konsep tidak bisa dibuktikan benar atau salahnya, tidak bisa dikatakan bahwa orang yang tidak percaya (disbeliever) mempunyai sebuah miskonsepsi tentang konsep tersebut.

\section{Mendeteksi Miskonsepsi}

Identifikasi miskonsepsi merupakan cara untuk mendeteksi belajar siswa yang mengalami kesalahapahaman konsep/konsepsi siswa berbeda dengan para ahli (Nurlaili, 2012). Identifikasi miskonsepsi diperlukan dalam mengembangkan strategi untuk membentuk pengetahuan konsep yang benar pada masing-masing siswa. Mengidentifikasi miskonsepsi siswa bertujuan untuk membantu menempatkan kembali pengetahuan awal (prakonsepsi) mereka menjadi konsep yang dapat diterima secara sains (Taber, 2009;Anzar, Darwis \& Asdar, 2017). 
Sebagai salah satu alternatif yang digunakan untuk mengidentifikasi miskonsepsi adalah teknik Certainty of Response Index (CRI) yang dikembangkan oleh Saleem Hasan. CRI merupakan ukuran tingkat keyakinan/kepastian responden dalam menjawab setiap pertanyaan (soal) yang diberikan. CRI bertujuan untuk mengidentifikasi terjadinya miskonsepsi, sekaligus dapat membedakannya dengan tidak tahu konsep, yang merupakan ukuran tingkat keyakinan/kepastian responden dalam menjawab setiap pertanyaan (soal) yang diberikan. CRI biasanya didasarkan pada suatu skala, sebagai contoh, skala enam (0-5) seperti pada tabel 1 (Hasan, Bagayoko \& Kelley, 1999).

TABEL 1. CRI dan Kriterianya

\begin{tabular}{lll}
\hline CRI & Kriteria & Keterangan \\
\hline 0 & Totally guessed answer (menebak seluruhnya) & 100\% jawaban ditebak \\
1 & Almost guess (hampir menebak) & Unsur tebakan antara 75-99\% \\
2 & Not sure (ragu) & Unsur tebakan antara 50-74\% \\
3 & Sure (yakin atau benar) & Unsur tebakan antara 25-49\% \\
4 & Almost certain (hampir pasti) & Unsur tebakan antara 1-24\% \\
5 & Certain (pasti) & Tidak ada unsur tebakan sama sekali (0\%) \\
\hline
\end{tabular}

Angka 0 menandakan tidak tahu konsep sama sekali tentang metode yang diperlukan untuk menjawab suatu pertanyaan (jawaban ditebak secara total). Sementara angka 5 menandakan kepercayaan diri yang penuh atas kebenaran pengetahuan tentang aturan-aturan yang dipergunakan untuk menjawab suatu pertanyaan (soal), tidak ada unsur tebakan sama sekali.

Tabel 2 menunjukkan empat kemungkinan kombinasi dari jawaban (benar atau salah) dan CRI (tinggi atau rendah) untuk tiap responden secara individu. Untuk suatu pertanyaan yang diberikan kepada seorang responden, jawaban benar dengan CRI rendah menandakan tidak tahu konsep, dan jawaban benar dengan CRI tinggi menunjukkan penguasaan konsep yang tinggi. Jawaban salah dengan CRI rendah menandakan tidak tahu konsep, sementara jawaban salah dengan CRI tinggi menandakan terjadinya miskonsepsi.

TABEL 2. Ketentuan untuk Membedakan antara Tahu Konsep, Miskonsepsi dan Tidak Tahu Konsep untuk Responden secara Individu

\begin{tabular}{lll}
\hline Kriteria Jawaban & CRI rendah $(<\mathbf{2 , 5})$ & CRI tinggi $(>\mathbf{2 , 5})$ \\
\hline Jawaban benar & $\begin{array}{l}\text { Jawaban benar tapi CRI rendah } \\
\text { berarti tidak tahu konsep (lucky } \\
\text { guess) }\end{array}$ & $\begin{array}{l}\text { Jawaban benarti menguasai konsep dengan } \\
\text { baik }\end{array}$ \\
Jawaban salah & $\begin{array}{l}\text { Jawaban salah dan CRI rendah } \\
\text { berarti tidak tahu konsep }\end{array}$ & $\begin{array}{l}\text { Jawaban salah tapi CRI tinggi } \\
\text { berarti terjadi miskonsepsi }\end{array}$ \\
\hline
\end{tabular}

(Sumber: Hasan, Bagayoko \& Kelley, 1999)

\section{Teori Konstruktivisme}

Konstruktivisme adalah suatu pendekatan yang berkeyakinan bahwa orang secara aktif membangun atau membuat pengetahuannya sendiri dan ditentukan berdasarkan pengalamannya (Paradesa, 2015). Konstruktivisme adalah sebuah filosofi pembelajaran yang dilandasi premis bahwa dengan merefleksikan pengalaman, kita membangun, mengkonstruksi pengetahuan pemahaman kita tentang dunia tempat kita hidup. Konstruktivisme melandasi pemikiran bahwa pengetahuan bukanlah sesuatu yang given dari alam, tetapi pengetahuan merupakan hasil konstruksi (bentukan) aktif manusia itu sendiri. Setiap kita akan menciptakan hukum dan model mental kita sendiri, yang kita pergunakan untuk menafsirkan dan menerjemahkan pengalaman. Belajar, dengan demikian semata - mata sebagai suatu proses pengaturan model mental seseorang untuk mengakomodasi pengalaman - pengalaman baru (Putri, 2017). 
Penelitian terkait miskonsepsi ditinjau dari teori konstruktivisme telah dilakukan oleh Sopiany dan Rahayu (2019), dimana hasil penelitian tersebut menunjukkan bahwa dari prinsip teori konstruktivisme terjadinya miskonsepsi pada siswa disebabkan oleh dua faktor, yaitu faktor internal dan faktor eksternal. Faktor internal yaitu kurang menguasai pengetahuan dasar, kesalahan menggunakan konsep matematika dan tidak dapat menyelesaikan masalah dalam bentuk soal cerita. Sedangkan faktor eksternal yaitu minat yang kurang dan motivasi yang rendah.

Prinsip-prinsip konstruktivisme, yaitu: 1) Mengaitkan semua aktivitas pembelajaran dalam perkembangan kemandirian terhadap semua masalah atau tugas; 2) Mendukung siswa dalam perkembangan kemandirian untuk semua masalah dan tugas; 3) Merancang tugas yang otentik; 4) Rancang lingkungan tugas dan pembelajaran untuk merefleksikan kompleksitas dari lingkungan bahwa siswa harus dapat menggunakannya pada akhir masa belajarnya; 5) Memberikan siswa kepercayaan dalam proses untuk mengembangkan solusi; 6) Merancang lingkungan belajar untuk mendukung dan menantang cara berpikir siswa; 7) Mendorong munculnya ide-ide dan melawan pandangan-pandangan dan konteks lainnya; dan 8) Memberikan kesempatan dan mendukung refleksi apa yang telah dipelajari dan proses pembelajarannya (Nurhidayati, 2017). Prinsip teori konstruktivisme yang dimaksud dalam penelitian ini adalah lingkungan belajar, pengetahuan awal siswa, kemampuan siswa, keaktifan siswa dalam pembelajaran dan pengalaman belajar siswa.

\section{METODE PENELITIAN}

Jenis penelitian ini merupakan penelitian kualitatif dengan menggunakan pendekatan deskriptif. Subjek penelitian ini adalah 5 siswa kelas 9 yang mengalami miskonsepsi terbanyak dengan nilai terendah. Pengambilan subjek penelitian didasarkan pada hasil tes diagnostik miskonsepsi setiap siswa.

Teknik pengumpulan data yang digunakan adalah tes dan wawancara. Instrumen dalam penelitian ini meliputi tes diagnostik miskonsepsi siswa yang terdiri dari beberapa butir soal uraian disertai dengan skor tingkat kepercayaan (CRI) dan pedoman wawancara. Semua instrumen yang digunakan dalam penelitian ini telah divalidasi oleh para validator ahli. Data yang diperoleh akan dianalisis dengan langkah-langkah kondensasi data, penyajian data, dan penarikan kesimpulan.

\section{HASIL DAN PEMBAHASAN}

TABEL 3. Subjek Penelitian dalam Tes Diagnostik Miskonsepsi

\begin{tabular}{llll}
\hline Inisial Subjek & Kode Subjek & Nilai & Karakteristik Subjek \\
\hline VY & S1 & 32 & $\begin{array}{l}\text { Miskonsepsi pada konsep penjumlahan } \\
\text { dan pengurangan perkalian, } \\
\text { penyederhanaan pecahan bentuk aljabar } \\
\text { RFS }\end{array}$ \\
S2 & 43 & $\begin{array}{l}\text { Miskonsepsi pada konsep penjumlahan } \\
\text { dan pengurangan, perpangkatan, } \\
\text { penyederhanaan pecahan bentuk aljabar } \\
\text { Miskonsepsi pada konsep perkalian, } \\
\text { pembagian pecahan bentuk aljabar } \\
\text { Miskonsepsi pada konsep perkalian, } \\
\text { perpangkatan pecahan bentuk aljabar } \\
\text { Miskonsepsi pada konsep perpangkatan } \\
\text { pecahan bentuk aljabar }\end{array}$ \\
FNI & S3 & 44 & 56 \\
\hline
\end{tabular}


Pengambilan data pada penelitian ini dilakukan dengan pemberian tes diagnostik miskonsepsi siswa dan wawancara. Pertama, tes diagnostik diberikan pada seluruh siswa kelas 9. Selanjutnya dipilih lima subjek yang mengalami miskonsepsi terbanyak. Adapun subjek yang dipilih dalam penelitian ini disajikan pada Tabel 3 .

Kelima subjek yang terpilih akan diwawancarai untuk mengetahui faktor penyebab miskonsepsi siswa ditinjau dari prinsip-prinsip teori belajar konstruktivisme.

\section{Lingkungan Belajar}

Saat proses belajar mengajar, siswa akan berinteraksi dengan lingkungannya. Sehingga siswa membutuhkan lingkungan belajar yang nyaman, tenang, jauh dari kebisingan dan tentunya harus mendukung untuk belajar. Lingkungan belajar yang kondusif diperlukan agar siswa dapat berkonsentrasi dengan baik sehingga dapat menyerap pelajaran dengan mudah. Jika lingkungan belajar siswa kurang kondusif akan membuat siswa terhambat dalam menyerap pelajaran. Oleh karena itu, lingkungan belajar perlu didesain agar mendukung kegiatan belajar sehingga dapat meningkatkan kenyamanan siswa untuk melakukan kegiatan belajar.

\section{TRANSKRIP 1}

S2-P01 : "Ketika kamu belajar atau mengerjakan tugas dari sekolah di rumah, apakah kamu dibimbing?"

S2-J01 : "Tidak kak."

S2-P02 : "Kenapa?"

S2-J02 : "Karena orang di rumah saya, masing-masing sibuk dengan urusannya kak."

S2-P03 : "Kapan biasanya kamu belajar atau mengerjakan tugas dari sekolah? Dan berapa lama?"

S2-J03 : "Malam kak. Waktunya tidak menentu kak, karena saya belajar ada jedanya kak. Jika saya capek, istirahat sebentar kemudian lanjut lagi kak."

S2-P04 : "Waktu masih belajar di sekolah, apakah kamu memperhatikan ketika guru sedang menjelaskan?"

S2-J04 : "Iya kak."

S2-P05 : "Saat guru sedang menjelaskan dan ada temanmu yang sedang mengobrol, apakah kamu akan ikut mengobrol atau tidak?"

S2-J05 : "Ikut mengobrol kak."

S2-P06 : “Apa yang kalian obrolkan? Tentang pelajaran?"

S2-J06 : "Sembarang kak tapi bukan tentang pelajaran."

S2-P07 : "Saat masih belajar matematika di sekolah, bagaimana kondisi kelasmu? Apakah ribut atau tidak?"

S2-J07 : "Ribut kak."

S2-P08 : "Jika kondisi kelasmu ribut, apakah kamu merasa terganggu?"

S2-J08 : "Merasa terganggu kak, karena tidak bisa didengar jelas apa yang guru katakan saat sedang menjelaskan di depan kelas."

Pada Transkrip 1, ketika mengerjakan pekerjaan rumah (PR), subjek tidak dibimbing melainkan kerja sendiri (S2-J01). Subjek biasanya mengerjakan tugas dari gurunya pada malam hari dengan waktu yang tidak menentu karena subjek belajar sambil istirahat/melakukan kegiatan lain (S2-J03). Ketika belajar di sekolah, subjek mengatakan memperhatikan saat gurunya menjelaskan (S2-J04) namun terkadang subjek ikut mengobrol saat temannya sedang mengobrolkan (S2-J05) hal yang tidak ada kaitannya dengan pelajaran (S2-J06). Selain itu, subjek juga mengatakan bahwa saat 
belajar di sekolah kadang kondisi kelasnya tidak kondusif/ribut (S2-J07) sehingga terkadang subjek merasa terganggu saat proses pembelajaran berlangsung (S2-J08).

Pada prinsip lingkungan belajar, faktor penyebab siswa mengalami miskonsepsi yaitu mengobrol saat guru menjelaskan dan situasi kelas yang tidak kondusif. Mengobrol saat guru menjelaskan akan menyebabkan siswa tidak dapat menerima ilmu yang disampaikan oleh guru dengan baik dan benar dan juga siswa akan mengalami kesulitan dalam memahami pelajaran yang sedang diajarkan. Sehingga hal itu dapat menyebabkan siswa mengalami miskonsepsi. Selain itu, situasi kelas yang tidak kondusif juga dapat memicu siswa mengalami miskonsepsi. Situasi kelas yang tidak kondusif akan membuat situasi pembelajaran menjadi tidak efektif. Sehingga siswa tidak bisa fokus dalam pembelajaran, dan mengakibatkan siswa tidak maksimal dalam memahami materi pembelajaran.

\section{Pengetahuan Awal Siswa}

Pengetahuan awal yang dimiliki oleh siswa merupakan hal yang sangat penting karena berpengaruh terhadap pemerolehan pengetahuan siswa pada jenjang pendidikan selanjutnya. Keberhasilan belajar bergantung bukan hanya pada lingkungan atau kondisi belajar, tetapi juga pada pengetahuan awal siswa (Rustaman, 2005; Yuliati, 2017). Berkaitan dengan pengetahuan awal, siswa mengetahui banyak hal dari pengalaman keseharian yang dialaminya bahkan dari sebelum jenjang sekolah formal, dan dari pengalaman ini lah pengetahuan awal siswa terbentuk. Namun sayangnya pengetahuan awal yang didapat siswa bisa benar ataupun bisa salah, hal ini disebabkan karena sumber informasi siswa tidak akurat dan pengalaman yang dialami siswa juga berbeda-beda.

\section{TRANSKRIP 2}

S1-P01 : "Apakah sebelumnya kamu sudah pernah mempelajari materi tentang pecahan? Kapan?"

S1-J01 : "Pernah kak. Ketika masih SD, tapi saya sudah lupa kelas berapa."

S1-P02 : "Kalau pecahan bentuk aljabar, sudah pernah?"

S1-J02 : "Iya kak, di kelas tujuh."

S1-P03 : "Apa yang masih kamu ingat atau pahami tentang materi pecahan yang sudah pernah kamu pelajari?"

S1-J03 : "Pecahan adalah bilangan yang memuat pembilang dan penyebut."

S1-P04 : "Selain itu?"

S1-J04 : "Pada pecahan terdapat operasi penjumlahan, pengurangan, perkalian, pembagian, perpangkatan dan penyederhanaan kak."

S1-P05 : "Apakah kamu masih ingat cara mengerjakan soal tentang pecahan?"

S1-J05 : "Sudah tidak terlalu ingat kak. Itu sebabnya, saya tidak terlalu yakin dengan jawaban saya dites yang kemarin kakak berikan."

S1-P06 : "Apa perbedaan pecahan biasa dengan pecahan bentuk aljabar? Bisa sebutkan contohnya?"

S1-J06 : "Pada pecahan biasa hanya memuat angka, contohnya 2 per 3. Sedangkan pada pecahan bentuk aljabar terdapat angka dan variabel, contohnya $2 x$ per $3 y . "$

S1-P07 : "Apakah operasi yang ada pada pecahan bentuk aljabar sama dengan operasi pada pecahan biasa?"

S1-J07 : "Iya, sama. Yang membedakan hanya bentuk aljabarnya kak."

S1-P08 : "Menurut kamu, konsep apa saja yang dibutuhkan untuk mempelajari pecahan bentuk aljabar?"

S1-J08 : "Konsep pecahan dan aljabar." 
Pada Transkrip 2, subjek mengatakan bahwa subjek sebelumnya telah mengetahui tentang materi pecahan yaitu saat sekolah dasar (S1-J01) dan materi pecahan bentuk aljabar yaitu saat kelas tujuh (S1-J02). Ketika subjek ditanya apa yang diingat pada materi tersebut, subjek menyebutkan mengenai pengertian dari pecahan yaitu bilangan yang memuat pembilang dan penyebut (S1-J03), operasi yang ada pada pecahan seperti penjumlahan, pengurangan, perkalian dan lain-lain (S1-J04). Namun subjek mengatakan sudah tidak terlalu ingat mengenai cara menyelesaikan soal terkait operasi pecahan (S1-J05).

Selain itu, subjek juga menyebutkan terkait perbedaan pecahan biasa dengan pecahan bentuk aljabar. Subjek mengatakan bahwa pecahan biasa hanya memuat angka sedangkan pecahan bentuk aljabar memuat angka dan variabel (S1-J06). Subjek juga mengatakan bahwa operasi yang ada pada pecahan bentuk aljabar sama dengan operasi yang ada pada pecahan biasa, yang membedakan hanya bentuk aljabarnya (S1-J07). Menurut subjek konsep yang dibutuhkan untuk mempelajari pecahan bentuk aljabar yaitu pecahan dan aljabar (S1-J08).

Pada prinsip mengenai pengetahuan awal siswa, faktor penyebab siswa mengalami miskonsepsi yaitu pengetahuan awal siswa yang rendah bahkan keliru/salah. Pengetahuan awal siswa yang rendah bahkan keliru/salah, dapat mempengaruhi pemahaman siswa terhadap materi selanjutnya yang berkaitan dengan pengetahuan awal yang dimilikinya. Miskonsepsi dalam pembelajaran matematika akan sangat fatal dikarenakan konsep-konsep matematika saling terkait antara satu dengan yang lainnya, sehingga rendahnya bahkan kesalahan konsep diawal pelajaran akan berpengaruh terhadap pembelajaran selanjutnya (Nazar, Sulastri, Winarti \& Fitriana, 2010).

\section{Kemampuan Siswa}

Setiap siswa memiliki kemampuan berbeda-beda dalam belajar matematika. Ada sebagian siswa yang mampu belajar lebih cepat dibandingkan dengan siswa yang lain. Kemampuan siswa dalam matematika sangatberpengaruh baik dalam hal memahami dan menyelesaikan masalah matematika. Semakin baik kemampuan siswa dalam memahami suatu konsep maka semakin kecil kemungkinan munculnya miskonepsi.

\section{TRANSKRIP 3}

\begin{tabular}{|c|c|c|}
\hline S4-P01 & & "Menurut kamu, materi apa yang berkaitan dengan pecahan di kelas sembilan?" \\
\hline S4-J01 & & "Perpangkatan" \\
\hline S4-P02 & & "Berapa hasil dari $2 a^{2}$ per $b^{3}$ dikali dengan $b^{2}$ per $c ? "$ \\
\hline S4-J02 & & "2 $a^{2} c$ per $b^{5}$ kak." \\
\hline$S 4-P 03$ & & "Alasannya?" \\
\hline S4-J03 & & $\begin{array}{l}\text { "Saya melakukan operasi perkalian dengan cara perkalian silang. Jadi } 2 a^{2} \text { dikali } \\
\text { dengan c hasilnya } 2 a^{2} c \text {, kemudian } b^{3} \text { dikali dengan } b^{2} \text { hasilnya } b^{5} k a k . "\end{array}$ \\
\hline S4-P04 & & "Mengapa $b^{3}$ dikali dengan $b^{2}$ hasilnya $b^{5}$, kenapa bukan $b^{6} ? "$ \\
\hline S4-J04 & & $\begin{array}{l}\text { "Seingat saya kak, jika variabel yang sama dikali, maka pangkatnya } \\
\text { dijumlahkan. Jadi } 3 \text { ditambah } 2 \text { hasilnya 5, sehingga diperoleh } b^{5} . "\end{array}$ \\
\hline S4-P05 & & "Ide nya kamu dapat dari mana?" \\
\hline S4-J05 & & "Sesuai pemahaman saya." \\
\hline S4-P06 & & "Sudah pernah diberikan soal seperti ini sebelumnya?" \\
\hline S4-J06 & 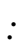 & "Pernah kak." \\
\hline S4-P07 & & $\begin{array}{l}\text { "Jika soalnya perpangkatan bilangan negatif, apakah kamu bisa mengerjakannya } \\
\text { atau tidak?" }\end{array}$ \\
\hline S4-J07 & & $\begin{array}{l}\text { "Tidak terlalu bisa kak karena menurutku sedikit rumit dan tidak terlalu } \\
\text { pahamka kak. Apalagi guru jarang memberikan latihan soal perpangkatan } \\
\text { yang pangkatnya bilangan negatif, lebih sering diberikan latihan soal } \\
\text { perpangkatan yang pangkatnya bilangan positif." }\end{array}$ \\
\hline
\end{tabular}


Pada Transkrip 3, subjek menerapkan konsep yang tidak tepat ketika melakukan operasi perkalian pecahan bentuk aljabar. Namun subjek menerapkan konsep yang tepat saat menjawab soal yang diberikan terkait perpangkatan pecahan bentuk aljabar. Subjek sudah mampu mengkonstruksi hubungan antar konsep operasi perpangkatan dengan konsep operasi perkalian. Hal ini dapat dilihat dari jawaban yang diberikan oleh subjek. Pada langkah awal, subjek menerapkan konsep yang tidak tepat saat melakukan operasi perkalian pecahan bentuk aljabar, dimana subjek melakukan operasi perkalian silang (S4-J03).

Selanjutnya, pada saat mengalikan variabel yang sama dengan pangkat yang berbeda, subjek menerapkan konsep yang tepat yaitu dengan menjumlahkan pangkat dari variabel tersebut (S4J04). Subjek mengatakan bahwa ide penyelesaian diperoleh dari pemahamannya (S4-J05). Subjek juga mengatakan bahwa soal yang diberikan oleh guru lebih sering yang pangkatnya bilangan positif dibanding negatif (S4-J07). Sehingga jika diberikan soal perpangkatan yang pangkatnya bilangan negatif, subjek mengalami kesulitan dalam menyelesaikannya (S4-J07).

Pada prinsip mengenai kemampuan siswa, faktor penyebab siswa mengalami miskonsepsi yaitu kurangnya variasi contoh soal dan latihan soal yang guru berikan. Kurangnnya variasi contoh soal dan latihan soal yang guru berikan, dapat membuat siswa mengalami kesulitan dalam mengerjakan soal yang jarang atau bahkan tidak pernah dikerjakan sebelumnya. Sehingga akan mengakibatkan siswa kurang mampu menyelesaikan soal tersebut dengan baik dan benar.

\section{Keaktifan Siswa dalam Pembelajaran}

Keaktifan siswa merupakan hal yang penting dalam proses pembelajaran. Melalui keaktifan siswa, guru dapat mengetahui apakah masih terjadi miskonsepsi pada diri siswa atau tidak. Selain itu, turut aktifnya siswa selama proses pembelajaran membuat siswa menjadi lebih aktif untuk bertanya jika terdapat materi yang kurang dipahaminya, tentu hal ini dapat membantu siswa untuk mengurangi kesalahan konsep yang diterima selama ini.

\section{TRANSKRIP 4}

S5-P01 : "Apa yang kamu lakukan jika menemukan materi yang tidak atau sulit kamu pahami?"

S5-J01 : "Bertanya kak."

S5-P02 : "Bertanya sama siapa?"

S5-J02 : "Sama teman, kadang juga sama guru kak."

S5-P03 : "Lebih sering bertanya ke guru atau teman?"

S5-J03 : "Teman kak karena kadang saya malu-malu bertanya sama guru."

S5-P04 : "Bagaimana kesan kamu terhadap pelajaran matematika?"

S5-J04 : "Menurut saya, pelajaran matematika memiliki daya tarik tersendiri kak sehingga saya bersemangat untuk mempelajarinya."

S5-P05 : "Menurut kamu, apakah belajar matematika itu menyenangkan atau membosankan?"

S5-J05: "Menyenangkan kak"

S5-P06 : "Alasannya?"

S5-J06 : "Karena gurunya baik dan sabar dalam mengajar dan membimbing kak."

S5-P07 : "Apakah kamu rajin mencatat materi ketika belajar matematika?"

S5-J07 : "Rajin kak."

Pada Transkrip 4, subjek mengatakan jika mengalami kesulitan dalam memahami pelajaran, subjek lebih sering bertanya ke teman kelasnya yang lebih paham dibanding ke guru (S5-J03). Alasan subjek jarang bertanya ke guru karena merasa malu (S5-J03). Ketika ditanya mengenai kesan terhadap pembelajaran matematika, subjek mengatakan bahwa pelajaran matematika adalah pelajaran yang memiliki daya tarik tersendiri sehingga membuat subjek bersemangat 
untuk mempelajarinya (S5-J04). Selain itu, subjek merasa senang saat belajar matematika (S5J05) karena gurunya baik dan sabar dalam mengajar dan membimbing (S5-J06) dan subjek juga rajin mencatat materi selama proses pembelajaran matematika (S5-J07).

Pada prinsip mengenai keaktifan siswa dalam pembelajaran, faktor penyebab siswa mengalami miskonsepsi yaitu malu bertanya pada guru. Malu bertanya pada guru akan membuat siswa mengalami kesulitan dalam memahami materi dan mengakibatkan siswa tidak dapat menyelesaikan tugasnya dengan baik. Selain itu, malu bertanya juga tidak dapat membuat pemahaman siswa semakin berkembang.

\section{Pengalaman Belajar Siswa}

Banyak konsepsi dan miskonsepsi anak terbentuk ketika anak berinteraksi dengan alam. Hal ini didukung oleh teori konstruktivisme dimana pengetahuan siswa dikontruksi atau dibangun oleh siswa sendiri dari interaksi mereka dengan benda, kejadian dan lingkungan. Pada saat siswa berinteraksi dengan lingkungan belajarnya berarti siswa mengkonstruksi pengetahuan berdasarkan pengalamannya. Ketika proses kontruksi pengetahuan terjadi pada siswa, sangat besar kemungkinan terjadinya kesalahan dalam proses mengkontruksi karena secara alami siswa belum terbiasa mengkontruksi pengetahuan sendiri secara tepat, apalagi jika tidak didampingi sumber informasi yang jelas dan akurat. Dengan kata lain, pengalaman sangat berpengaruh dalam terbentuknya miskonsepsi yang terjadi pada siswa (Budhi, 2018).

\section{TRANSKRIP 5}

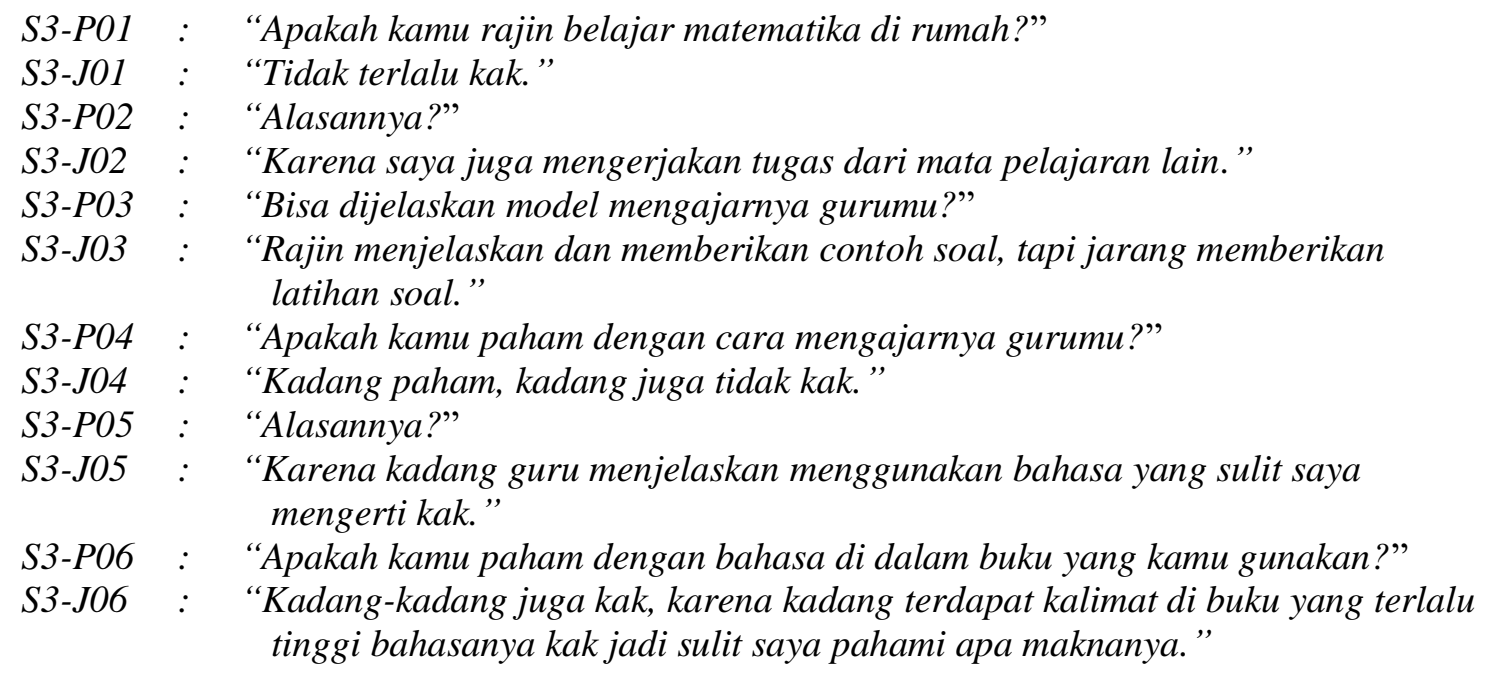

Pada Transkrip 5, subjek mengatakan tidak terlalu sering belajar di rumah (S3-J01). Ketika sedang belajar di sekolah, subjek mengatakan guru rajin dalam menjelaskan materi dan memberikan contoh soal tetapi jarang memberikan latihan soal (S3-J03). Saat guru sedang menjelaskan, terkadang subjek merasa sulit memahami penjelasan guru karena guru menggunakan bahasa yang sulit dimengerti (S3-J05). Selain itu, saat proses pembelajaran berlangsung, subjek terkadang sulit memahami bahasa yang ada pada buku paket yang digunakan (S3-J06). Hal ini membuat subjek mengalami kesulitan dalam memahami konsep pecahan bentuk aljabar.

Pada prinsip mengenai pengalaman belajar siswa, faktor penyebab siswa mengalami miskonsepsi yaitu jarang belajar atau mengulang kembali materi yang telah dipelajari di sekolah, kurangnya pemberian latihan soal, bahasa guru dan buku paket yang sulit dipahami. Jarang belajar atau mengulang kembali materi yang telah dipelajari di sekolah dan kurangnya 
pemberian latihan soal akan menyebabkan siswa dengan mudah melupakan materi yang telah dipelajarinya. Jika siswa memiliki ingatan yang lemah terhadap materi yang telah dipelajarinya, maka siswa akan mengalami kesulitan saat mengerjakan soal materi baru yang berkaitan dengan materi yang telah dipelajari sebelumnya. Selain itu, bahasa guru dan buku paket yang sulit dipahami akan membingungkan siswa. Sehingga membuat siswa mengalami penafsiran yang salah dari makna sebenarnya. Hal ini dapat mengakibatkan miskonsepsi yang dialami siswa akan semakin parah.

\section{KESIMPULAN}

Ditinjau dari prinsip-prinsip pada teori belajar konstruktivisme terjadinya miskonsepsi siswa disebabkan oleh faktor internal dan faktor eksternal. Faktor internal antara lain mengobrol saat guru menjelaskan, pengetahuan awal siswa yang rendah bahkan keliru/salah, malu bertanya pada guru, jarang belajar atau mengulang kembali materi yang telah dipelajari di sekolah. Sedangkan faktor eksternal meliputi situasi kelas yang tidak kondusif, kurangnya variasi contoh/latihan soal yang guru berikan, bahasa guru dan buku paket yang sulit dipahami.

Penelitian lain yang berkaitan dengan faktor penyebab miskonsepsi siswa dapat dikembangkan pada materi lain dan ditinjau dari aspek lain. Penelitian ini juga dapat dikembangkan dengan menganalisis lebih lanjut tentang letak, jenis-jenis maupun cara memperbaiki miskonsepsi yang terjadi pada siswa. Selain itu, dalam mengidentifikasi miskonsepsi yang dialami siswa dapat menggunakan tes diagnostik dengan model yang berbeda.

\section{DAFTAR PUSTAKA}

Anzar, Darwis, M., \& Asdar. (2017). Mengidentifikasi Miskonsepsi Logaritma Siswa SMA Kelas X. Issues in Mathematics Education, 1(1). 33-37.

Artiawati, P. R., Muliyani, R., \& Kurniawan, Y. (2016). Identifikasi Kuantitas Siswa yang Miskonsepsi Menggunakan Three Tier-Test Pada Materi Gerak Lurus Beraturan (GLB). Jurnal Ilmu Pendidikan Fisika, 3(1). 5-7.

Budhi, H.S. (2018). Model Pembelajaran Berbasis Pengalaman untuk Meminimalkan Miskonsepsi Siswa pada Materi Cahaya. Thabiea : Journal of Natural Science Teaching, 1(2). 125-129.

Hasan, S., Bagayoko, D., \& Kelley, E.L. (1999). Misconceptions and the Certainty of Response Index (CRI). Physics Education, 34(5). 294-299.

Jannah, A.U. (2018). Analisis Miskonsepsi Siswa dalam Pembelajaran Pecahan Aljabar pada Siswa SMP Kelas VIII (Skripsi, tidak dipublikasikan). Universitas Nusantara PGRI, Kediri.

Leinhardt, G., Zaslavsky, O., \& Stein, M.K. (1990). Functions, Graphs, and Graphing: Tasks, Learning, and Teaching. Review of Educational Research, 60(1). 1-64.

Malikha, Z., \& Amir, M.F. (2018). Analisis Miskonsepsi Siswa Kelas V-B Min Buduran Sidoarjo Pada Materi Pecahan Ditinjau dari Kemampuan Matematika. Pi: Mathematics Education Journal, 1(2). 75-81.

Munawaroh, F. (2017). Analisis Miskonsepsi Siswa pada Materi Pecahan Bentuk Aljabar ditinjau dari Minat Belajar Siswa Kelas VIII SMP Negeril4 Surakarta Tahun Ajaran 2016/2017 (Skripsi, tidak dipublikasikan). Universitas Sebelas Maret, Surakarta. 
Muzangwa, J., \& Chifamba, F. (2012). Analysis of Errors and Misconceptions in The Learning of Calculus by Undergraduate Students. International Journal: Acta Didactica Napocensia, 5(2). 1-10.

Nazar, M., Sulastri, Winarti, S., \& Fitriana, R. (2010). Identifikasi Miskonsepsi Siswa Pada Konsep Faktor-Faktor yang Mempengaruhi Laju Reaksi. Jurnal Biologi Edukasi, 2. 4953.

Ningrum, R.W., \& Budiarto, M.T. (2016). Miskonsepsi Siswa SMP pada Materi Bangun Datar Segiempat dan Alternatif Mengatasinya. MATHEdunesa: Jurnal Ilmiah Pendidikan Matematika, 1(5). 66-59.

Nurhidayati, E. (2017). Pedagogi Konstruktivisme dalam Praksis Pendidikan Indonesia. Indonesian Journal of Educational Counseling, 1(1). 1-14.

Nurlaili, E.W. (2012). Analisis Miskonsepsi Siswa Kelas VII SMP Negeri 16 Surakarta Tahun Ajaran 2011/2012 pada Pembelajaran Matematika Materi Pokok Segitiga (Skripsi, tidak dipublikasikan). Universitas Sebelas Maret, Surakarta.

Paradesa, R. (2015). Kemampuan Berpikir Kritis Matematis Mahasiswa melalui Pendekatan Konstruktivisme pada Matakuliah Matematika Keuangan. Jurnal Pendidikan Matematika RAFA, 1(2). 306-325.

Putri, K.K. (2017). Pengembangan Perangkat Pembelajaran Berbasis Pendekatan Saintifik pada Materi Lingkaran untuk Meningkatkan Prestasi Belajar Matematika Siswa SMP Kelas VIII (Skripsi, tidak dipublikasikan). Universitas Negeri Yogyakarta, Yogyakarta.

Rahmah, N., Dassa, A., \& Ramdani, R. (2019). Analisis Miskonsepsi dalam Menyelesaikan Soal Cerita Matematika Ditinjau dari Gaya Kognitif pada Siswa Kelas VIII SMP Buq'atun Mubarakah Kota Makassar. SIGMA (Suara Intelektual Gaya Matematika), 11. 143-151.

Rustaman, N. (2005). Strategi Belajar Mengajar Biologi. Malang: UM Press.

Salamah, A.A.A. (2015). Analisis Miskonsepsi Siswa Menggunakan Pendekatan Kognitif Menurut Teori Piaget Pada Materi Optik Kelas VIII Mts Nu Mu'allimat Kudus (Skripsi, tidak dipublikasikan). Universitas Islam Negeri Walisongo, Semarang.

Savitri, M.E. (2014). Analisis Miskonsepsi Siswa pada Materi Pecahan dalam Bentukk Aljabar ditinjau dari Gaya Kognitif Siswa Kelas VIII di SMP Negeri 2 Adimulyo Kabupaten Kebumen Tahun Ajaran 2013/2014 (Tesis, tidak dipublikasikan). Universitas Sebelas Maret, Surakarta.

Sopiany, H.N., \& Rahayu, W. (2019). Analisis Miskonsepsi Siswa ditinjau dari Teori Konstruktivisme pada Materi Segiempat. Jurnal Pendidikan Matematika, 13(2). 185200.

Suparno, P. (2013). Miskonsepsi dan Perubahan Konsep dalam Pendidikan Fisika. Jakarta: PT. Gasindo.

Taber, K. S. (2009). Challenging Misconceptions In The Chemistry Classroom: Resources To Support Teachers. Educació Química EduQ, 4. 13-20.

Yuliati, Y. (2017). Miskonsepsi Siswa pada Pembelajaran IPA serta Remediasinya. Jurnal Bio Educatio, 2(2). 50-58 